\title{
Developing Practicum Module of Particle Dynamics Based on Scientific Methods to Improve Students' Science Process Skills
}

\author{
Irnin Agustina Dwi Astuti ${ }^{\mathrm{a}^{*}}$, Indra Yahdi Putra ${ }^{\mathrm{a}}$, Yoga Budi Bhakti ${ }^{\mathrm{a}}$ \\ ${ }^{a}$ Department of Physics Education, Faculty of Mathematics and Natural Sciences, Indraprasta PGRI University, Jakarta, Indonesia \\ *Corresponding author: Bougenville Street J No 107, Jatimulya, Tambun Selatan, Bekasi, West Java, Indonesia. E-mail addresses: \\ irnin.agustina@gmail.com
}

\begin{tabular}{|c|c|}
\hline a $r$ t i c l e i n f o & a b s t r a c t \\
\hline $\begin{array}{l}\text { Article history: } \\
\text { Received: } 24 \text { February } 2018 \\
\text { Received in revised form: } 23 \text { March } \\
2018 \\
\text { Accepted: } 12 \text { December } 2018 \\
\text { Available online: December } 2018 \\
\text { Keywords: } \\
\text { Module of practicum } \\
\text { Scientific method } \\
\text { 4D models } \\
\text { Particle dynamic } \\
\text { Science process skills }\end{array}$ & $\begin{array}{l}\text { The existence of basic competence skills in the current national curriculum requires learners } \\
\text { to have skilled expertise in the field of physics, which one of them is students' science } \\
\text { process skills. Students' science process skills become students' guide in understanding } \\
\text { physics concepts. The availability of resources and guidance in conducting practicum is } \\
\text { very small, so teachers have difficulties when they want to conduct practicum in learning } \\
\text { activities because of the lack of resources available. Therefore, we need a scientifically } \\
\text { based practicum module to increase students' science process skills. This development } \\
\text { research using 4-D method (Define, Design, Develop, and Disseminate). In the } \\
\text { development of this module, the researchers only come to the third stage of the four stages. } \\
\text { Validation results from experts get an average score of } 81 \% \text { interpretation which means that } \\
\text { the module is included in the criteria worthy of use in learning even with the notes of } \\
\text { experts to revise some of the components present in this module so that this module } \\
\text { complies with existing standards. The results of the analysis of student responses to the } \\
\text { practicum module obtained a total average of } 80 \% \text { with the category is "strong." This shows } \\
\text { almost all the students gave a positive response to the scientific-based practicum module. } \\
\text { The development of scientific-based practicum modules can improve science process skills } \\
\text { of the students, with the average score of students' science process skills before using a } \\
\text { scientific-based practicum module of } 2.54 \text { and the average score of students' science } \\
\text { process skills after using a scientific-based practicum module of } 3.20 \text {. }\end{array}$ \\
\hline
\end{tabular}

2018 Scientiae Educatia: Jurnal Pendidikan Sains

\section{Introduction}

Physics is one branch of Natural Sciences. Science learning in the process emphasizes providing a direct experience that aims to develop competencies to explore and understand the natural environment scientifically (Astuti \& Bhakti, 2018). One that can provide direct experience in a learning process is through practicum. The availability of learning resources especially in existing physics practicum modules is still lack. Observations from the researchers found that the teacher had difficulty doing practicum when in class, due to a lack of available lab modules as a complement to practicum activities for students. Though one aspect that can make physics interesting for the students is in practicum. The importance of practicum in physics learning is in its way to shape scientific understanding and experience (Boisandi, 2017). 
The 2013 curriculum creates new challenges among teachers because practicum modules must not only be by existing material but also must be able to make students active and engage their critical thinking. 2013 curriculum based on character and competence wants to change the pattern of education from result orientation to process orientation (Rakhmawati \& Azmi, 2016). Meanwhile, the skills of the scientific process and scientific attitudes also support the 2013 curriculum assessment. Science process skills and scientific attitudes possessed will help students solve problems by using systematic scientific steps like a scientist (Rosmalinda et al., 2013). The method used in the 2013 curriculum is the scientific method. The Scientific approach is closely related to the scientific method (Mansyur et al., 2016).

Scientific method generally involves observation activities needed for the formulation of hypotheses or collecting data, (Sani, 2014). The application of scientific methods in learning involves process skills such as observing, classifying, measuring, predicting, explaining, and concluding (Budiyanto et al., 2016). The scientific method is based on authentic assessment, and the learning steps do not involve students optimally (Chusni et al., 2017). Similarly, the results of research (Kustijono \& Wiwin, 2014) and (Aryani, 2014) which state that teachers are still constrained in the 2013 curriculum, have not been able to carry out scientific learning, have not been able to prepare appropriate media and have not been able to carry out assessment according to the 2013 curriculum standards .

In the 2013 curriculum, students are required to be active, where students can learn independently (student center). Process skills can develop the ability to observe, classify, interpret, predict, apply, plan research, and communicate (Ambarsari et al., 2013). Students' science process skills support the existence of scientific curriculum 2013. Through process skills, the concepts obtained by students will be more meaningful because students' thinking skills will be more developed.

Modules are teaching materials that are packaged intact and systematically, which contain a set of planned learning experiences and are designed for students to master specific learning goals (Daryanto, 2013). Whereas, according to Susilana and Riyana (2009), the module is a program package that is arranged in a certain unit form and designed in such a way as to study interests. Modules as one of the teaching materials have one characteristic, is the principle of independent learning (Lasmiyati \& Harta, 2014). Through independent learning, the module as a complement to student learning, both learning modules and lab modules. Modules can be 
said to be good if they use learning theory that can support the achievement of basic competencies (Furqan et al., 2016). According to Russell, as cited in Wena (2009), the characteristics of the module include self-containment, relying on individual differences, the existence of associations, the use of various media, active participation of students, direct reinforcement, supervision of evaluation strategies.

Based on the background and explanation above, the researcher develops a practicum module that is in accordance with existing needs and is easy to use by the teacher and also students, the modules is also adjusted to the 2013 curriculum that is nationally applicable and based on scientific methods that aim to improve students' science process skills.

\section{Methods}

This type of research is Research and Development (R and D). R and D is a research method with the aim of producing certain products and testing the effectiveness of the products (Sugiyono, 2011). This research is development research that uses 4-D methods, namely define, design, develop, and disseminate (Fatimah \& Mufti, 2014). This research was carried out using a flow diagram as shown in Figure 1.

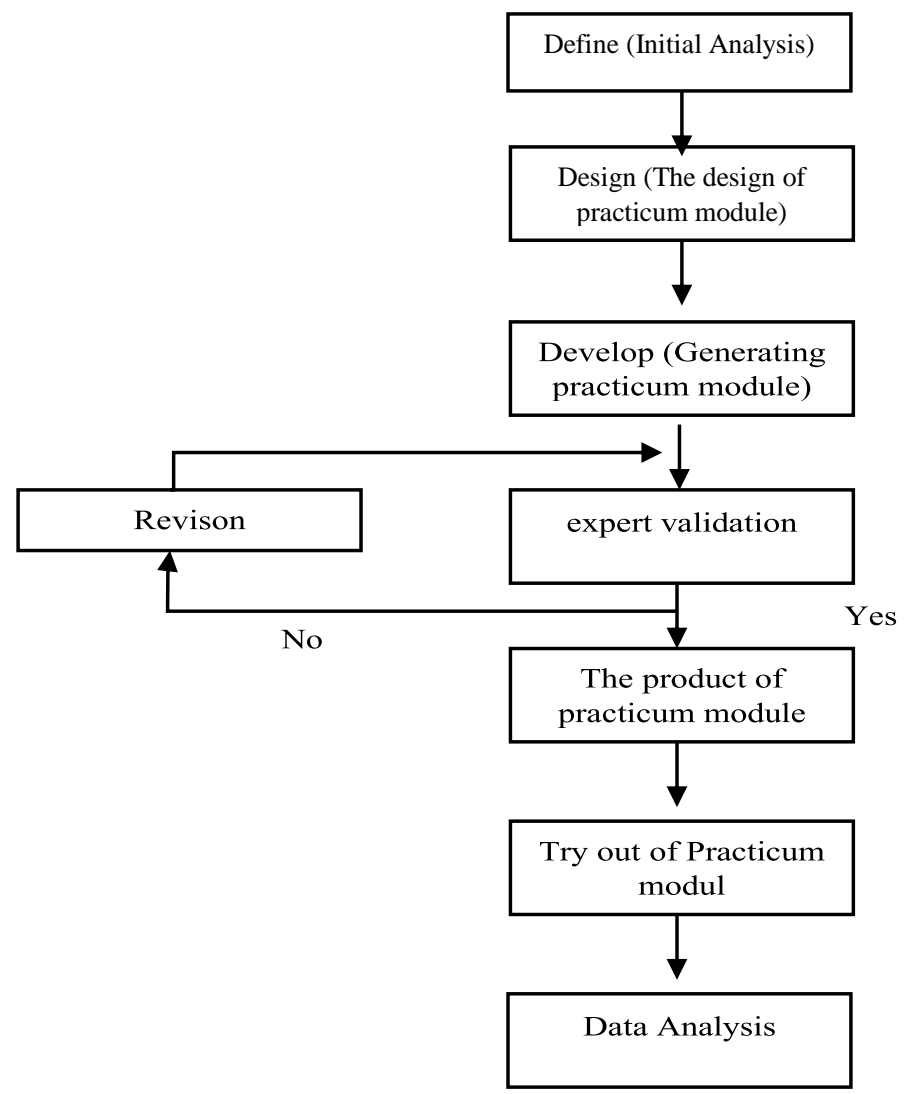

Figure 1. Research Flowchart 
To get the required data in the form of feasibility tests by experts, the instruments used in the form of questionnaires as in table 1.

Table 1. Questionnaire of Module Eligibility

\begin{tabular}{|c|c|c|}
\hline No & Indicators & Statements \\
\hline 1. & Content Validation & $\begin{array}{l}\text { a. The practicum module supports practicum activities } \\
\text { b. The practicum module is based on the students' } \\
\text { need. } \\
\text { c. It covers all materials which should be learned } \\
\text { by the students. } \\
\text { d. The basic theory is organized systematically } \\
\text { e. The concepts relate to daily life } \\
\text { f. The materials are based on the recent curriculum }\end{array}$ \\
\hline 2. & Language & $\begin{array}{l}\text { a. The fonts used are easy to read } \\
\text { b. The formulas are clear and easy to read. } \\
\text { c. The provisions of information are clear, } \\
\text { relevant, and do not cause double meaning. } \\
\text { d. The sentences are based on Indonesian Perfected } \\
\text { Spelling System. } \\
\text { e. The sentences are easy to understand } \\
\text { f. The use of language is effective and efficient. } \\
\text { g. The selections of language are simple and } \\
\text { communicative }\end{array}$ \\
\hline 3. & Structure & $\begin{array}{l}\text { a. The title is clear } \\
\text { b. The materials are presented in a systematic order } \\
\text { c. It has an interesting illustration and relevance. } \\
\text { d. The figures and symbols presented are related to } \\
\text { the physic concepts. } \\
\text { e. The figure of experiment tool sets are presented } \\
\text { clearly }\end{array}$ \\
\hline 4. & Product Beneficial & $\begin{array}{l}\text { a. Engaging students' curiosity } \\
\text { b. Engaging students to be active during practicum } \\
\text { activity. } \\
\text { c. Increasing students' knowledge, experience, and } \\
\text { skills. }\end{array}$ \\
\hline
\end{tabular}

(Source: researcher)

Questionnaires are given to several validators who are experts in their fields. The questionnaire instrument analysis was used to test the feasibility of the product. This instrument uses a Likert scale. The answer categories provided are 4 for very good, 3 for good, 2 for enough, and 1 for very poor. Questionnaire answers were weighted 4,3,2,1 for positive statements and 1,2,3,4 for negative statements. Individual score results are stated as follows (Dasmo et al., 2017):

$$
\% \text { Score Interpretation }=\frac{\sum \text { Score of acquisition }}{\sum \text { Maximum score }} \times 100 \%
$$


The eligibility criteria for the products are presented in Table 2.

Table 2. Data Interpretation of Module Eligibility (Riduwan, 2011)

\begin{tabular}{ccc}
\hline No & Percentage & Notes \\
\hline 1 & $80 \%-100 \%$ & good/Valid \\
2 & $60 \%-79,99 \%$ & enough/ Valid \\
3 & $50 \%-59,99 \%$ & less / Valid \\
4 & $0-49,99 \%$ & bad (replaced) \\
\hline
\end{tabular}

To find out the response of students to the practicum module in the small class trials, it can be analyzed using below equations (Supardi, 2013):

$$
N R S=\frac{\sum R S}{R S_{\text {maximum }}} \times 100 \%
$$

Notes :

$N R S=$ The percentage of student responses $(\%)$;

$R S=$ student responses for each item;

RS maximum $=$ The total of student responses

After calculating the response value of students for each item statement, the next step is to determine the criteria for the percentage of student response values per item statement as follows:

Table 3. Criteria category of student responses to practicum modules (Supardi, 2013)

\begin{tabular}{cc}
\hline Interval Score & Category \\
\hline $0 \% \leq N R S<20 \%$ & Very Weak \\
$20 \% \leq N R S<40 \%$ & Weak \\
$40 \% \leq N R S<60 \%$ & Enough \\
$60 \% \leq N R S<80 \%$ & Strong \\
$80 \% \leq N R S<100 \%$ & Very Strong \\
\hline
\end{tabular}

After testing a small class to find out student responses, then a large class trial was conducted to determine the effectiveness of the practicum module on students' science process skills before and after treatment. Data techniques used include descriptive analysis, data requirements analysis, and hypothesis testing. Science process skills are assessed with a grid of observation sheets as in the following table:

Table 4. The grid of observation sheets for science process skills (Astuti et al., 2016)

\begin{tabular}{cl}
\hline No & \multicolumn{1}{c}{ Indicators } \\
\hline 1 & Observing teacher's demonstration \\
2 & Asking the application of particle dynamics \\
\hline
\end{tabular}




\begin{tabular}{|c|c|}
\hline No & Indicators \\
\hline 3 & Identifying tools, materials, and the result of an experiment conducted \\
\hline 4 & Adjusting the prediction made with the theory and the materials taught \\
\hline 5 & Determining the acceleration of earth gravity accurately \\
\hline 6 & Answering, asking, and giving solution or opinion in a group discussion \\
\hline 7 & $\begin{array}{l}\text { Writing and summarizing the result of the experiment, and writing the answer } \\
\text { on the module based on the result of the discussion }\end{array}$ \\
\hline 8 & Presenting the result of the discussion, accurately, and effectively \\
\hline 9 & Connecting the data from the experiment to the existing theory \\
\hline 10 & $\begin{array}{l}\text { Applying theory from any sources and the data from an experiment by } \\
\text { looking up to supporting references to strengthen the conclusion }\end{array}$ \\
\hline 11 & Selecting the relevant theories (references) \\
\hline 12 & $\begin{array}{l}\text { Concluding based on the experiment organized based on the objectives } \\
\text { revealed in the practice module }\end{array}$ \\
\hline
\end{tabular}

\section{Results and Discussion}

The development of this learning media uses a 4-D model of learning media design model. The 4-D development model was chosen because it is a suggested development model in the development of learning devices. This model consists of four stages of development, namely Define, Design, Develop, and Disseminate. The research flow is as it follows:

\subsection{Define Stage}

At this stage, the analysis begins with how the state, knowledge, skills and initial attitude of students to achieve the learning goals listed in the curriculum. From the analysis, it was produced that in physics learning, critical thinking skills in conducting experiments were still very minimal, because the teacher had difficulty in conducting the practicum. Scientific methods are very commonly used by scientists in the world in conducting research, namely observation, asking questions, submitting hypotheses, practicums/experiments, writing experimental results and making conclusions (Wijayanti, 2014). This method is considered ideal for teaching students to get used to practicum. Practical activities are considered important because they can provide learning experiences directly to students. They can apply theories that have been learned and can develop students' science process skills (Trianto, 2009).

\subsection{Design Stage}

At this stage, the researcher will design a lab module that meets the criteria of a good lab module. Writing practicum modules is carried out with steps namely 1) Formulation of basic competencies that must be mastered comes from the national curriculum content standards set 
by the government; 2) Designing from the technical side, such as adjusting to scientific methods that are generally applicable in the world, the form and arrangement of practicum modules; 3) Determine the form of assessment; and 4) Compilation of appropriate material.

In the development of the practicum module, material from class XI was chosen, namely rotational dynamics. In this material, it requires a concept of understanding that must be directly practiced by students, because if only the theory, the students will be confused in understanding deeply about this concept. Also, the material used is relatively easy to obtain and does not make it difficult for teachers and students. In this concept, there are also many applications to the real world that we can immediately make an example to students of how important this concept is.

\subsection{Develop Stage}

At this stage, a physics practicum module was oriented towards the scientific approach to the concept of rotational dynamics. The purpose of this stage is to produce a module that has been revised based on input from experts. Among them is module validation by experts followed by revisions, limited trials whose results are the basis of revisions, and further trials in the real class. In further trials to find out the science process skills of students by using scientific-based lab modules.

The practicum module that has been developed is then consulted with several expert lecturers so that they can get input for development and improvement before being tested. This stage aims to find out one aspect of product quality development, namely the validity aspect. This is done by testing product validity by experts, and getting suggestions and criticisms from the validator on the product being developed. Validation data obtained were then analyzed and revised. The revised product is a development and improvement based on expert validation (Trianto, 2009).

The scientific-based lab module developed has several characteristics including practical steps by scientific steps, namely (observing, asking, gathering information, associating, communicating). The practicum module consists of several experimental steps accompanied by images that function so that students can practice independently without direction from the teacher, so the teacher is only a facilitator. The contents of the module contained a table of observations and data analysis used to write the results of the student practice. 
The feasibility test of this scientific-based lab module is validated by three experts who are competent in their fields. The following are the results of the module validation assessment presented in Table 5. Figure 3 and 4 shows cover and feasibility of practicum module.

Table 5. The Result of the Module Validation

\begin{tabular}{lcc}
\hline No & Indicator & Average \\
\hline 1. & Content Eligibility Aspect & 3,44 \\
2. & Language Aspect & 3,19 \\
3. & Structure Aspect & 3,00 \\
4. & Product Beneficial Aspect & 3,33 \\
\hline & Average & 3,24 \\
\hline
\end{tabular}

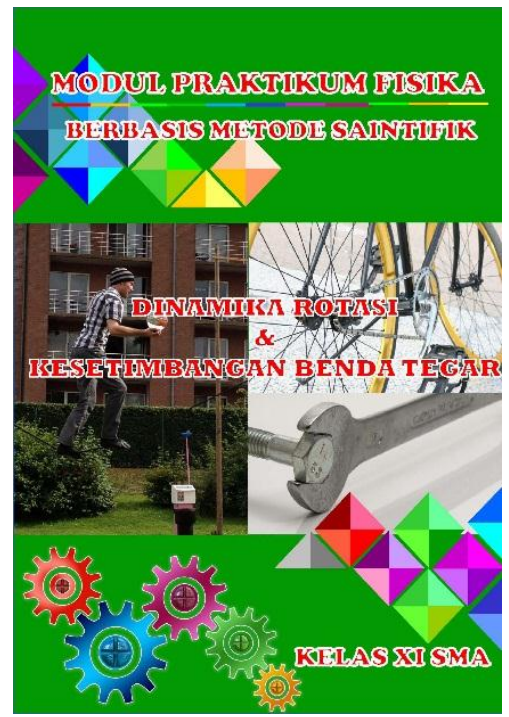

Figure 3. The Displayed cover of the practicum module

Based on the criteria table, the validation assessment data analysis obtained an average total score of 3.24 or $81 \%$ and included in the criteria of "feasible." Improvements are made based on the suggestions or comments of experts, namely 1) Clarify the concept of scientific method again, 2) Add a more attractive introduction before entering the lab material, 3) Giving quotes from sources, 4) In the observation section better add illustrations, 5) Giving description of the image and description of the table, and 6) Writing the formula must be clarified again.

After the scientific-based practicum module was revised then the next stage of the small class trial was to $20 \mathrm{XI}$ grade students of Depok 3 Public High School to find out students' responses to the practicum module. From the results of the analysis of student responses to the practicum module, the total average was 4.0 or $80 \%$ with the "strong" category. This condition shows that almost all students respond positively to the scientific-based lab module that has been made. 
Scientific-based practicum module is applied to class XI Depok State High School students to find out the science process skills of students. Science process skills are the ability to use thoughts, reason, and actions efficiently and effectively to achieve a certain outcome (Bhakti $\&$ Astuti, 2018). The results of the average science process skills of students are shown in table 6.

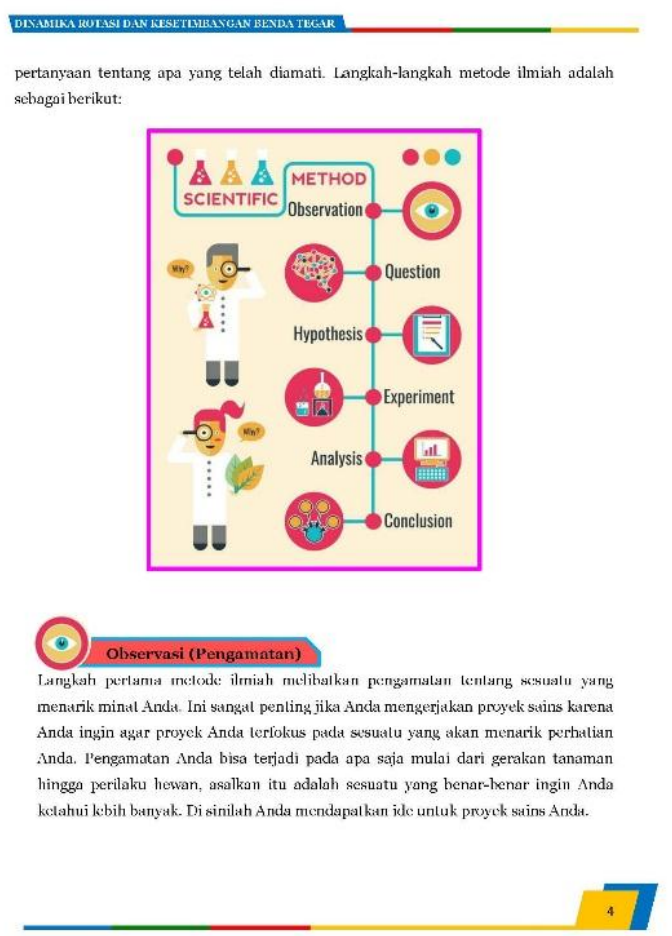

Figure 4. The Content Feasibility of the Practicum Module

Table 6 . The average value of student process science skill before and after treatment

\begin{tabular}{ccc}
\hline No indicator & $\begin{array}{c}\text { Student Science Process Skill } \\
\text { Before }\end{array}$ & \begin{tabular}{c} 
After \\
\hline 1
\end{tabular} \\
2 & 2,4 & 3,6 \\
3 & 2,3 & 3,2 \\
4 & 3 & 3,4 \\
5 & 3,6 & 3 \\
6 & 3,4 & 3,2 \\
7 & 2,3 & 3,2 \\
8 & 2 & 3,5 \\
9 & 2,1 & 3 \\
10 & 3 & 2,8 \\
11 & 2,4 & 2,9 \\
12 & 2 & 3,2 \\
Average & $\mathbf{2 , 5 4}$ & 3,4 \\
& & $\mathbf{3 , 2 0}$ \\
\hline
\end{tabular}


An increase in students' science process skills using scientific-based lab modules, with an average score before action 2.54 and a mean score after action 3.20. This shows that students have good skills in carrying out practicum work by the scientific method. The development of scientific-based lab modules is very helpful for students to experimental physics so that not only the results of experiments that students get but students also better understand the concept of physics properly.

This practicum module based on the scientific method can be used as a support for teachers in learning at school. In physics learning, students are trained to understand the science process correctly which is closely related to daily life in finding concepts through observation or practicum activities (Sugiyarti et al., 2015; Handika \& Wangid, 2013). In addition to science process skills, another thing that must be owned by a student is the scientific attitude (Rosmalinda et al., 2013). In the practicum module with the scientific method developed there are steps to observe, ask questions, collect information (practicum), process information, and communicate (practical reports and presentations). This module can show students learning independently (student center) by scientific methods so that students look active when carrying out learning.

The scientific attitude is the attitude shown by scientists when they carry out scientific activities in this scientific activity that is capable of the practicum module based on this scientific method. Students not only master the concepts of physics in theory, solve problems with mathematical formulas, but also able to prove the concepts of physics scientifically through the stages of the scientific method. With the interaction with the scientific approach other than the mastery of concepts, students can develop the process of creativity (Aktamis \& Ergin, 2008). The scientific approach in the learning process has a positive impact on student learning outcomes; this is because in the scientific approach students find themselves the concepts learned (Jaya et al., 2014).

Dasril et al., (2014) explained that a good book, which is an interesting book, is equipped with pictures and descriptions. Visually the presentation and research of concepts, symbols, pictures, tables, and illustrations are presented clearly and interestingly. In the science-based practicum module presented images and instructions that become markers of scientific methods by the 2013 curriculum. So that with this practicum module students can measure their respective abilities in practicum. According to Lasmiyati and Harta (2014) the existence 
of LKS or modules, students have the opportunity to develop their thinking skills through a process of specialization, conjecturing, justification and generalization. Learning with modules is an independent learning approach that focuses on mastering competencies from study material that learners learn at a certain time according to their potential and conditions (Prabowo \& Palupi, 2013).

In line with his opinion, (Fidiana, Bambang, \& Pratiwi, 2012) students are more active learning with practicum modules because students have read the module, thus minimizing the possibility of students to copy their friends. Students become more active in practicum even though there are still students who are confused. Also, according to Budiono and Susanto (2006), the preparation of learning modules based on competency-based curriculum can improve competency in applying Newton's law in simple dynamics problems and can improve student learning independence. Another study conducted by Lahra et al., (2017), an openended approach can be combined in the form of a practicum module that aims to provide students with independence in overcoming problems with physics learning especially those related to practicum. Thus the practicum module can support the learning process of physics. Practicum performance in the laboratory is a complex activity process that involves many elements (Yuberti et al., 2016) so that complementary modules are needed. As a reinforcer in applying the scientific method, the experimental method or practicum equipped with a practicum module is needed with the aim that students can construct their knowledge in the learning process.

Development of particle dynamics practicum module based on the scientific method which is equipped with scientific method steps is expected to increase student activeness in practicum activities, foster an attitude of independence in learning and students can construct knowledge according to scientific methods so that they get deep learning in physics learning activities.

\section{Conclusion}

Based on the results and discussion, it can be concluded that the scientific-based lab module on particle dynamics material is feasible to be used as a tool and guide to physics practicum learning based on the evaluation by the validator. The results of expert evaluations obtain an average score of 3.24 or $81 \%$ and are included in the criteria of "feasible" to be used in learning at school. From the results of the analysis of student responses to the practicum 
module, the total average was 4.0 or $80 \%$ with the "strong" category. This condition shows that almost all students respond positively to the scientific-based lab module that has been made. The development of scientific-based lab modules can improve students' science process skills, with the average value of science process skills of students before using scientificbased lab modules of 2.54 and the average value of science process skills of students after using scientific-based lab modules of 3.20.

Suggestions that can be obtained for further research is to develop a physics practicum module based on scientific methods for different physical material. The practicum module can be equipped with basic competencies that are by the curriculum used in the school.

\section{References}

Aktamis, H., \& Ergin, Ö. (2008). The Effect of Scientific Process Skills Education on Students' Scientific Creativity, Science Attitudes and Academic Achievements. In AsiaPacific Forum on Science Learning and Teaching, 9(1), 1-21.

Ambarsari, W., Santosa, S., \& Maridi, M. (2013). Penerapan pembelajaran inkuiri terbimbing terhadap keterampilan proses sains dasar pada pelajaran biologi siswa kelas VIII SMP Negeri 7 Surakarta. Jurnal Pendidikan Biologi, 5(1), 81-95. Avalable Online: https://jurnal.uns.ac.id/bio/article/view/5626.

Aryani, M. F. (2014). Studi kasus penerapan pendekatan saintifik pada guru-guru di SMA N 1 Bawang (studi pada tahun ajaran 2013/2014). Economic Education Analysis Journal, 3(3), 558-563. Available

Online: https://journal.unnes.ac.id/sju/index.php/eeaj/article/view/4511.

Astuti, I. A. D., \& Bhakti, Y. B. (2018). Interactive learning multimedia based Microsoft excel on the temperature and heat. Unnes Science Education Journal, 7(1), 1-6. DOI:10.15294/usej.v7i1.21355 .

Astuti, R., Sunarno, W., \& Sudarisman, S. (2016). Pembelajaran IPA dengan pendekatan ketrampilan proses sains menggunakan metode eksperimen bebas termodifikasi dan eksperimen terbimbing ditinjau dari sikap ilmiah dan motivasi belajar siswa. Prosiding Seminar Biologi, 13(1), 338-345. Available Online: http://jurnal.fkip.uns.ac.id/index.php/prosbio/article/view/9524.

Bhakti, Y. B. \& Astuti, I. A. D. (2018). The influence process of science skill and motivation learning with creativity learn. Journal of Education and Learning, 12(1), 30-35. DOI: 10.11591/edulearn.v12i1.6912 .

Boisandi, A. (2017). Pengembangan modul eksperimen fisika material solar cell berbasis TPACK. Edukasi: Jurnal Pendidikan, 15(1), 1-10. Available Online: http://journal.ikippgriptk.ac.id/index.php/edukasi/article/view/402

Budiono, E., \& Susanto, H. (2006). Penyusunan dan penggunaan modul pembelajaran berdasar kurikulum berbasis kompetensi sub pokok bahasan analisa kuantitatif untuk soalsoal dinamika sederhana pada kelas X semester I SMA. Jurnal Pendidikan Fisika Indonesia, 4(2), 80-87. DOI: 10.15294/jpfi.v4i2.166

Budiyanto, M. A. K., Waluyo, L., \& Mokhtar, A. (2016). Implementasi pendekatan saintifik dalam pembelajaran di pendidikan dasar di Malang. Proceeding Biology Education Conference, 13(1), 46-51. Available Online: https://jurnal.uns.ac.id/prosbi/article/view/5648 
Chusni, M. M., Setya, W., Agustina, R. D., \& Malik, A. (2017). Peningkatan kemampuan menyusun rencana pelaksanaan pembelajaran (RPP) berbasis saintifik bagi calon guru fisika. Scientiae Educatia: Jurnal Pendidikan Sains, 6(2), 125-143. DOI:0.24235/sc.educatia.v6i2.1952

Daryanto. (2013). Menyusun modul. Yogyakarta: Gava Media.

Dasmo, D., Astuti, I. A. D., \& Nurullaeli, N. (2017). Pengembangan pocket mobile learning berbasis android. Jurnal Riset dan Kajian Pendidikan Fisika, 4(2), 71-77. DOI: 10.12928/jrkpf.v4i2.7363

Dasril, D., Yulkifli, Y., \& Haris, V. (2014). Pengembangan modul praktikum berbasis paikem pada materi fisika SMA Kelas X semester II. Edusainstika, 1(1), 15-17. Available Online: http://repository.unp.ac.id/17992/1/2015\%20Dasril\%20dan\%20Yulkifli\%20Edusainstika\% 202012\%20224-858-1-PB.pdf

Djamarah, S., B., \& Zain, A. (2006). Strategi belajar mengajar. PT Rineka Cipta.

Fatimah, S., \& Mufti, Y. (2014). Pengembangan media pembelajaran IPA-fisika smartphone berbasis android sebagai penguat karakter sains siswa. Jurnal Kaunia, 10(1), 59-64. Available Online: http://ejournal.uin-suka.ac.id/saintek/kaunia/article/view/1066

Fidiana, L., Bambang, S., \& Pratiwi, D. (2012). Pembuatan dan implementasi modul praktikum fisika berbasis masalah untuk meningkatkan kemandirian belajar siswa kelas XI. UPEJ Unnes Physics Education Journal, 1(2), 38-44. DOI: 10.15294/upej.v1i2.1377

Furqan, H., Yusrizal, Y., \& Saminan, S. (2017). Pengembangan modul praktikum berbasis inkuiri untuk meningkatkan keterampilan proses sains dan hasil belajar siswa kelas $\mathrm{X}$ di SMA Negeri 1 Bukit Bener Meriah. Jurnal Pendidikan Sains Indonesia, 4(2), 124-129. Available Online: http://www.jurnal.unsyiah.ac.id/JPSI/article/view/7589.

Handika, I., \& Wangid, M. N. (2013). Pengaruh pembelajaran berbasis masalah terhadap penguasaan konsep dan keterampilan proses sains siswa kelas V. Jurnal Prima Edukasia, 1(1), 85-93. DOI: 10.21831/jpe.v1i1.2320

Jaya, G. W., Patasik, B., Sembel, E. K. R. N., Subagiyo, L., \& Yunus, M. (2014). Penerapan pendekatan saintifik melalui metode eksperimen pada pembelajaran fisika siswa kelas $\mathrm{X}$ MIA 3 SMA Negeri 1 Tenggarong (materi suhu dan kalor). Saintifika, 16(2), 22-29. Available Online: https://jurnal.unej.ac.id/index.php/STF/article/view/2410

Kustijono, R., \& Wiwin, E. (2014). Pandangan guru terhadap pelaksanaan kurikulum 2013 dalam pembelajaran fisika SMK di Kota Surabaya. Jurnal Pendidikan Fisika dan Aplikasinya (JPFA), 4(1), 1-14. DOI: 10.26740/jpfa.v4n1.p1-14

Lahra, A. S., Hasan, M., \& Mursal, M. (2017). Pengembangan modul praktikum berbasis pendekatan open ended untuk meningkatkan kreativitas siswa. Jurnal Pendidikan Sains Indonesia, 5(1), 36-43. Available Online: http://jurnal.unsyiah.ac.id/JPSI/article/view/8405

Lasmiyati, L., \& Harta, I. (2014). Pengembangan Modul Pembelajaran untuk Meningkatkan Pemahaman Konsep dan Minat SMP. Pythagoras: Jurnal Pendidikan Matematika, 9(2), 161-174. DOI: 10.21831/pg.v9i2.9077

Mansyur, Y. A., Kartimi, K., \& Roviati, E. (2016). Penerapan pendekatan saintifik berbasis konservasi pada materi keanekaragaman makhluk hidup untuk meningkatkan hasil belajar siswa di SMPN 1 Gempol. Scientiae Educatia: Jurnal Pendidikan Sains, 5(1), 61-70. DOI: 10.24235/sc.educatia.v6i2.2000

Mulyasa, E. (2006). Menjadi guru profesional menciptakan pembelajaran kreatif dan menyenangkan. Yogyakarta: PT Remaja Rosdakarya.

Prabowo, S., \& Palupi, A. E. (2013). Pengembangan modul pembelajaran CNC II untuk meningkatkan efektivitas belajar mahasiswa program studi D3 teknik mesin fakultas teknik Universitas Negeri Surabaya. Jurnal Pend. Teknik Mesin, 1(3), 77-85. Available Online: 
http://jurnalmahasiswa.unesa.ac.id/index.php/jurnal-pendidikan-teknikmesin/article/view/2246/baca-artikel

Rakhmawati, S., \& Azmi, N. (2016). Analisis pelaksanaan Kurikulum 2013 ditinjau dari standar proses dalam pembelajaran biologi kelas X di SMA Negeri 1 Krangkeng. Scientiae Educatia: Jurnal Pendidikan Sains, 5(2), 156-164. Available Online: http://syekhnurjati.ac.id/jurnal/index.php/sceducatia/article/view/973

Riduwan. (2011). Skala Pengukuran Variabel-variabel Penelitian. Alfabeta: Bandung.

Rosmalinda, D., Rusdi, M., \& Hariyadi, B. (2013). Pengembangan modul praktikum kimia SMA berbasis PBL (Problem Based Learning). Edu-Sains: Jurnal Pendidikan Matematika dan Ilmu Pengetahuan Alam Universitas Jember, 2(2), 1-7. Available Online: https://online-journal.unja.ac.id/index.php/edusains/article/view/1666

Sani, R. A. (2014). Pembelajaran saintifik untuk implementasi kurikulum 2013. Jakarta: Bumi Aksara.

Sugiyarti, H., Sunarno, W., \& Aminah, N. S. (2015). Pembelajaran fisika dengan pendekatan saintifik menggunakan metode proyek dan eksperimen ditinjau dari kreativitas dan kemampuan berpikir kritis siswa. INKUIRI Jurnal Pendidikan IPA, 4(4), 34-42. Available Online: https://jurnal.uns.ac.id/inkuiri/article/view/9586

Sugiyono. (2011). Metode penelitian kuantitatif, kualitatif dan $R \& D$. Bandung: Alfabeta.

Supardi, U., S. (2013). Aplikasi statistika dalam penelitian. Jakarta: PT Prima Ufuk Semesta.

Susilana, R., \& Riyana, C. (2009). Media pembelajaran. Jakarta: CV Wacana Prima.

Trianto. (2009). Mengembangkan model pembelajaran tematik. Surabaya: Prestasi Pustaka Raya.

Wena, M. (2009). Strategi pembelajaran inovatif kontemporer suatu tinjauan konseptual operasional. Jakarta: Bumi Aksara.

Wijayanti, A. (2014). Pengembangan autentic assesment berbasis proyek dengan pendekatan saintifik untuk meningkatkan keterampilan berpikir ilmiah mahasiswa. Jurnal Pendidikan IPA Indonesia, 3(2), 102-108. DOI: 10.15294/jpii.v3i2.3107

Yuberti, Y., Nomida, D., \& Nuriah, T. (2016). The assessment of student performance in the practicum activity of basic physics course. TARBIYA: Journal of Education in Muslim Society, 3(1), 121-130. DOI: 10.15408/tjems.v3i1.3397 